Canadian

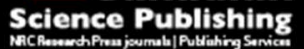

Canadian Journal of Civil Engineering Revue canadienne de génie civil

\title{
DESIGN OF COLD RECYCLED MIXES WITH ASPHALT EMULSION AND PORTLAND CEMENT
}

\begin{tabular}{|r|l|}
\hline Journal: & Canadian Journal of Civil Engineering \\
\hline Manuscript ID & cjce-2016-0111.R1 \\
\hline Manuscript Type: & Article \\
\hline Date Submitted by the Author: & 15 -Jun-2016 \\
\hline Complete List of Authors: & $\begin{array}{l}\text { Bessa, Iuri; Universidade de Sao Paulo, Department of Transportation } \\
\text { Engineering } \\
\text { Almeida, Letícia; Universidade de Sao Paulo, Department of Transportation } \\
\text { Engineering } \\
\text { Vasconcelos, Kamilla; Univeristy of Sao Paulo - Polytechnique School, } \\
\text { Department of Transportation Engineering } \\
\text { Bernucci, Liedi; Universidade de Sao Paulo }\end{array}$ \\
\hline Keyword: & $\begin{array}{l}\text { environmental < MANUSCRIPT CLASSIFICATION, experimental research < } \\
\text { type of paper to review, highways < Transportation }\end{array}$ \\
\hline &
\end{tabular}




\section{DESIGN OF COLD RECYCLED MIXES WITH ASPHALT EMULSION AND PORTLAND CEMENT}

\section{Iuri S. Bessa (corresponding author)}

Department of Transportation Engineering

Universidade de São Paulo (USP)

Av. Prof. Almeida Prado, Travessa 2, No. 83 - Cidade Universitária

São Paulo, SP, Brazil, 05508-070

Phone: +55 (11) 3091.6090

Fax: +55 (11) 3091.5716

Email: iuribessa@usp.br

\section{Letícia R. Almeida}

Department of Transportation Engineering Universidade de São Paulo (USP)

Av. Prof. Almeida Prado, Travessa 2, No. 83 - Cidade Universitária São Paulo, SP, Brazil, 05508-070

\section{Kamilla L. Vasconcelos}

Department of Transportation Engineering

Universidade de São Paulo (USP)

Av. Prof. Almeida Prado, Travessa 2, No. 83 - Cidade Universitária

São Paulo, SP, Brazil, 05508-070

\section{Liedi L. B. Bernucci}

Department of Transportation Engineering

Universidade de São Paulo (USP)

Av. Prof. Almeida Prado, Travessa 2, No. 83 - Cidade Universitária

São Paulo, SP, Brazil, 05508-070

Word count: $6,439+2$ tables +10 figures $=9,439$ words 


\begin{abstract}
Recycling techniques are important tools for rehabilitation of old and deteriorated asphalt pavements. The production of cold recycled mixes using reclaimed asphalt pavement (RAP) as aggregates provides economic benefits as it decreases transportation costs, energy consumption and gas emissions. Despite that, there is no internationally accepted methodology to design this type of mix. The present research evaluated the design of cold recycled mixes through different compaction methods and varying asphalt emulsion and cement contents. Different curing temperatures and periods were analyzed in order to propose a faster and more practical method for mix design in laboratory. Mechanical tests performed indicated that specimens compacted by the Marshall hammer provide similar results when varying asphalt emulsion and cement contents, while the Proctor hammer compaction was able to better capture the influence of these materials. The temperature of $60^{\circ} \mathrm{C}$ associated with shorter curing time is believed to be good for design purposes.
\end{abstract}

Keywords: cold recycled mixes design; compaction methods; mechanical behavior; curing processes. 


\section{INTRODUCTION}

In the past few decades, cold recycling of asphalt mixes has become an important technique to be used for the rehabilitation of old deteriorated asphalt pavements. Many researchers have focused on these techniques, and on the major benefits that they can provide in comparison to reconstructions with the use of new materials. Cold recycling brings benefits related to the reuse of materials, and the reduction of energy consumption and gas emission, which are directly related to environmental and economic advantages. The total, or partial, restoration of existing pavement layers with addition of new materials can be considered as recycling. The main objective of this process is to produce new pavement layers that are capable of resisting traffic load and different environmental conditions.

The petroleum crises in the 1970 s increased the study of recycled materials for asphalt pavements application. In the past decades, the reclaimed asphalt pavement (RAP) has been widely used in the composition of recycled asphalt mixes, especially for the rehabilitation of damaged pavement structures. The use of hydraulic binder has also increased in order to promote better rigidity to these materials.

According to ARRA (2001), the restoration of asphalt pavements is usually done by adding new layers while removing, or not, the damaged ones. The aggregates generally used in pavement construction are extracted from quarries that explore natural resources, initiating a production and transportation cycle that might lead to several environmental impacts, and that can also be very expensive. In road construction, the use of new materials can cost at least $50 \%$ more than the use of any type of recycled material (MnDOT 2000). 
Despite the well-known advantages and efficiency of cold recycled mixes, there is no internationally accepted standard to be used for their laboratory mix design, in spite of a few existing manuals and guidelines, such as the Wirtgen Cold Recycling Manual (2012). The present study has the main purpose of evaluating different methodologies used in the design of cold recycled mixes with addition of asphalt emulsion and Portland cement. The research included the evaluation of different emulsion, cement and water contents with the use of different compaction methods (Marshall and Proctor). It also included the mechanical characterization of recycled mixes after different curing processes. The emulsion and cement contents were varied among 2, 3 and 4\%, and 0,1 and 2\%, respectively. Mechanical tests for unconfined compressive strength (UCS), resilient modulus (Mr), and indirect tensile strength (ITS) were performed for the different sets of mixes. Different curing processes included temperatures of $25,40,60$, and $100^{\circ} \mathrm{C}$, and time periods of $1,3,7,28,60$ and 90 days.

\section{BENEFITS OF RECYCLED ASPHALT PAVEMENTS}

The increasing environmental concerns related to the use of natural resources and energy consumption have been helpful in the development of new recycling techniques in civil engineering projects, including pavements design and construction. The incorporation of old materials to new asphalt mixes instead of using new materials only provides environmental advantages, as it saves resources and avoids impacts related to extraction and transportation of raw products (Chiu et al. 2008).

Chiu et al. (2008) evaluated the environmental impact of rehabilitating asphalt pavements using four different materials, which included three recycled asphalts: asphalt rubber, Glassphalt, and recycled hot mix asphalt (HMA), and one new HMA. They concluded that using the recycled 
HMA would reduce the eco-burden by $23 \%$ in comparison to the use of the traditional HMA. Also, the authors indicated that most of the eco-burden (42 to 50\%) provided by rehabilitation of asphalt pavements is due to energy consumption, which is a good indication of the advantages of using cold recycling techniques.

A study conducted by Thenoux et al. (2007) proposed three pavement structural rehabilitations techniques: asphalt overlay, reconstruction, and recycling with foamed asphalt. Energy consumption was calculated considering the performance of the equipment and machinery used within the three processes. The authors concluded that the energy consumption ratio between reconstruction and recycling could vary from 2.5 to 3.4 , depending on the design thickness proposed, which is directly related to the design traffic. The cold in place recycling with foamed bitumen had the lowest impact on the environment, reducing energy consumption, if compared to an asphalt overlay project and to the reconstruction project.

Motta et al. (2014) estimated energy and cost savings, and the reduction of polycyclic aromatic hydrocarbons (PAHs) when using WMA instead of HMA as asphalt pavements surface layers. The energy consumption reduction considered, i.e., the heating of aggregates and the heating of steam. The calculations lead to a saving of $15 \%$ in energy consumption. In relation to the fuel cost, the WMA would save approximately U\$740.00 per kilometer if compared to the HMA. Regarding the PAHs emissions, which can be very toxic to nature and humans, the authors performed an evaluation of both in lab and on field, and found that the concentration of these substances are approximately three times higher when mixing and compacting HMA. 
Giani et al. (2015) stated that the use of RAP coupled with the production of warm mix asphalt (WMA) is the key to a sustainable design of asphalt pavements, bringing environmental improvements. This technique would reduce carbon dioxide emissions in $12 \%$, while the energy and water consumptions would decrease in $15 \%$, each one, during the lifecycle of the road. Cold in place recycling decreases the use of new aggregates, the transport and the consumption of the plant. All of these aspects provide benefits in terms of carbon dioxide emissions.

Other types of recycled asphalt materials are also reused in new asphalt pavements structures or in the rehabilitation of old structures, such as the recycled asphalt shingles (RAS). Yang et al. (2014) performed a laboratory and a field case study on using this material in roads of Ontario, Canada. Their test results and field performances indicated RAS can be useful additive to hot mix asphalt if the mixes are correctly designed. Also, field testing showed that the surface friction of these structures are in good conditions, even when are subjected to different loading and environmental variables.

\section{COLD RECYCLING WITH ASPHALT EMULSION AND PORTLAND CEMENT}

\subsection{Design of cold recycled mixes}

The use of cold recycling techniques has been explored and developed in the past several years by different researchers around the world. Different compaction methods, aggregate size distributions, constituent materials, and curing processes have been proposed for the design of this type of mix. Kim and Lee (2006) used the Marshall compaction with 75 blows per face, while Recasens et al. (2000) and Baker et al. (2000) used the modified Proctor compaction and its standard parameters in order to obtain the optimum moisture content. Studies by Kuna et al. (2016) and Godenzoni et al. (2016) compared the use of Proctor and gyratory types of compaction; the first concluded that 140 
gyrations in the gyratory compactor provides density values close to the ones obtained for the Proctor compaction; the latter considered the Proctor compaction procedure for establishment of water content. Thanaya et al. (2009), Gao et al. (2014), Lee et al. (2016) and Tabakovic et al. (2016) proposed the use of gyratory compaction to produce samples of cold recycled mixes. Lee and $\operatorname{Kim}$ (2003) recommended that at least four asphalt emulsion contents should be tested and that the number of gyrations used should be adjusted to achieve densities values that are similar to the ones normally obtained for field specimens.

\subsection{Asphalt emulsion content}

The addition of asphalt emulsion to cold recycled mixes provides flexibility, enhance cohesion among the RAP particles, which increases permanent deformation resistance (Kavussi and Modarres 2010). Different researchers have tested several percentages of emulsion and water to define the optimum contents of these materials to be incorporated into cold recycled mixes. Many tests have been performed to achieve this purpose: Marshall stability (Niazi and Jalili 2009); construction and traffic densification indexes (Gao et al. 2014); fracture energy (Charmot et al. 2013); ITS and retained ITS evaluation (Silva et al. 2013). In general, a value of 2 or 3\% of asphalt emulsion has provided the best results for the different materials and gradations evaluated.

\subsection{Cement content}

Cement is usually added to cold recycled mixes to provide better rigidity and improve the mechanical performance throughout the time. Niazi and Jalili (2009) tested cold recycled mixes with asphalt emulsion with the addition of different hydraulic binders (cement and hydrated lime) and concluded that the use of $2 \%$ of cement would be the optimum content to increase the rigidity and the ITS values. Xu et al. (2011) produced cold recycled mixes with various cement contents 
and reported that the increasing percentage would lead to better moisture resistance. Samples with $0.5 \%$ of cement, or less, did not present good moisture damage resistance and presented low increase of tensile strength after 7 days of curing. The addition of $2.5 \%$ or more cement would probably lead to similar values of dry and wet ITS, but this amount of cement would provide brittleness and stiffness to the mixes what may lead to fatigue cracking issues.

\subsection{Curing of cold recycled mixes}

Previous laboratory tests and field data have indicated that the curing process, which includes the definition of temperature and time, have a significant impact on cold recycled mixes behavior (Kim et al. 2011). Past studies have proposed different temperatures and curing periods to be considered for this type of mix (Table 1). Several agencies indicate the use of room temperature (around $25^{\circ} \mathrm{C}$ ) for curing, with periods of time ranging from two hours up to three days.

Recently, a task group of many research laboratories from Europe, North America and South Africa developed a state of art and state of practice summary of processes to be used for specimen preparation and curing practices for cold recycled asphalt mixes. The study presented a review of scientific literature and practices done by different agencies on topics related to recycled asphalt mixes and to the evaluation of curing processes through field studies. The research concluded that the procedures for characterization controlling of cold recycled mixes are all in disagreement around the world. The only characterization that is common among the different standards and procedures is the gradation analysis. Compaction energy, temperature of curing, and curing time are controlled in different ways in the several laboratories and agencies studied (Tebaldi et al. 2014). 
The behavior of cold recycled mixes throughout their curing time has been widely studied and discussed. Modarres et al. (2011) reported a significant increase in stiffness of cold recycled mixes specimens after 28 days of curing. After 120 days, the rate of stiffness increase is very low, and the stiffness characteristics reach their ultimate stage. In relation to fatigue life, curing periods at $25^{\circ} \mathrm{C}$ did not have any major effect on their specimens. Samples cured after 7, 28, and 120 days presented similar results and similar fatigue life curve slopes.

\section{EXPERIMENTAL DESIGN}

In the present study, cold recycled mixes were designed using two different compaction methods, with RAP materials collected from an old deteriorated highway in Brazil, keeping the same aggregate size distribution (Figure 1). The limits are based on the Asphalt Academy (2009). The gradation curve is not in compliance with the limits provided, but it was kept unchanged because the original aggregate distribution size of the RAP material was used in a rehabilitation project in Brazil for the construction of the cold recycled mixture. The information about the field experiment of this rehabilitation project can be found elsewhere (Bessa et al. 2016). A study by Perraton et al. (2016) proved that these materials fragment during the Proctor compaction and this has a direct relation to the Los Angeles abrasion values and to the particles sizes. The fragmentation test was performed to characterize the RAP materials used in the present research. The results (Figure 2) indicate that the percent passing control sieve (PCS) is lower with higher temperatures. It is important to state that, for this study, the RAP fraction used in the test was $5 / 10 \mathrm{~mm}$ (with mean particle size of $7.1 \mathrm{~mm}$ ). The Los Angeles abrasion test resulted in $28 \%$ of mass loss; and the percentage of flat/elongated RAP particles was $0 \%$ (ratio of 1:5). 
As for the constituent materials used in the composition of the cold recycled mixes with the water and the RAP aggregate, a CP II Portland cement and a controlled-setting cationic polymer-modified asphalt emulsion (CRS-2P). The Marshall hammer (75 blows per side) was used to produce $100 \mathrm{~mm}$-diameter and $63 \mathrm{~mm}$-height specimens, according to ASTM D6926 (2010), as previously reported by Bessa et al. (2014); the other method used the standard Proctor compaction hammer to produce specimens that did not have the regular Proctor mold size, but $100 \mathrm{~mm}$-diameter and 200mm-height specimens. This was done in order to meet the triaxial test sample size. The main objective of this research was to define the better methodology to be used for the design purposes of this type of mix. Figure 3 presents the experimental design matrix done in the present research.

As Marshall compaction did not result in any major change on the mechanical behavior of the cold recycled mixes with variation of its constituents' content (Bessa et al. 2016), another compaction method and sample size was evaluated with respect to the mechanical behavior. The Marshall compaction used 75 blows per face and its mold height was $63 \mathrm{~mm}$. For the compaction using the Proctor hammer, a 200mm-height and the modified compaction energy was used.

Initially three emulsion contents $(2,3$, and $4 \%)$ were added to the cold recycled mixes along with $1 \%$ of cement. The samples were submitted to the curing process after they were extruded from the molds. The curing period was 7 days, and the temperature was controlled in a chamber at $25^{\circ} \mathrm{C}$. After that, the emulsion content was fixed at $3 \%$ with the cement contents varying in 0,1 , and $2 \%$. The amount of water presented in the asphalt emulsion composition (38\%) was accounted during the blending of the materials. The compaction curves (dry density versus water content) are presented in Figure 4. 


\subsection{Asphalt emulsion content variation}

Samples with 2, 3, and 4\% of asphalt emulsion were prepared in the laboratory using the Proctor hammer. The values of dry density obtained presented minor differences within the same emulsion content when the water content was changed. The differences were less than approximately $0.05 \mathrm{~g} / \mathrm{cm}^{3}$, which means that the cold recycled mixes tend to be very similar in terms of dry density independent of the water content added during their mixing (similar with the observed in the Marshall samples). This might be explained by the gradation curve of the material, which contains very low percentage of fine fractions; Dafalla (2013) found similar tendency for $100 \mathrm{~mm} \times 100 \mathrm{~mm}$ samples. The OMC, including the water from the asphalt emulsion, for each set of mixes would be $6.2 \%$ for the $2 \%$-mixes, $5.8 \%$ for the $3 \%$-mixes, and $5.3 \%$ for the $4 \%$-mixes. Although the similarities in the dry density results (also observed in other referenced studies), the authors used the curve's 'peak value' because of the simplicity required for the mixture design method, and also because it was consistent with the workability (in a qualitative way) observed in the samples preparation. The comparison between the compaction results leads to $3 \%$ asphalt emulsion selection. Tests for UCS were performed in each specimen. Figure 5 presents the results for each combination of emulsion and water contents.

In general, the variation in the water content did not have major influence on the results of UCS for any emulsion content. The strength tended to decrease with the addition of asphalt emulsion, i.e., mixes with $4 \%$ of emulsion resulted in lower UCS values. This occurred in spite of mixes with $2 \%$ of emulsion having lower density values. The authors believe that the UCS results are influenced by the emulsion content while the density values are much more influenced by the water content, rather than the emulsion content. 
The moisture loss during the curing period was also verified for each specimen. The results indicated that none of the specimens lost all of the water added during the compaction. An average value of $1.5 \%$ of water was kept inside the specimens' structure, which was very similar to what was reported by Batista and Antunes (2006). In general, the higher the moisture content added, the higher the loss of moisture content.

\subsection{Cement content variation}

The cement content of the recycled mixes was initially selected as $1 \%$, and new specimens with 0 and $2 \%$ of cement were prepared for comparison purposes. Only one sample for each condition was tested, once they were the same prepared for the compaction curve. The results indicated that there was a clear tendency of increasing strength with the increase in cement content. In relation to the $\mathrm{OMC}$, increasing the cement content led to higher values since the presence of finer particles tend to increase the surface area that should be lubricated with water. Figure 6 presents the results of UCS tests. UCS values for the mixes without cement were very low in comparison to those mixes with 1 or $2 \%$ of cement. The variation of water content did not influence the results.

\subsection{Conventional curing processes}

After the study involving the variation on cement, water, and emulsion contents, the study focused on the effects of different curing processes, which included different temperatures and periods of time. The emulsion, water and cement contents were fixed at 3.0, 5.5 (4.36\% of free water plus $1.14 \%$ of emulsion water), and $1.0 \%$, respectively, which are values normally used in the field, and also the ones that produced the best recycled mixes in the laboratory in terms of volumetric and mechanical properties. 
The first curing method was done at $25^{\circ} \mathrm{C}$ in a temperature-controlled chamber with variation on curing periods: $7,28,60$, and 90 days. For each time period, six specimens were compacted, with the same constituent's materials and volumetric characteristics. A six-sample set was tested for the resilient modulus, three for the ITS, and three for the UCS. The specimens had average dry density values of approximately $2,000 \mathrm{~kg} / \mathrm{m}^{3}$, independent of how much time they were submitted to curing before the mechanical test. The moisture content was verified before and after curing, and, after 28 days, the remaining water content was stabilized, and the steady state moisture content was in average $1.5 \%$. This might have been correspondent to the water that was used for the cement hydration. Triaxial Mr tests were performed for all the specimens compacted. Every curing period was tested in order to verify the increase on the rigidity throughout the time (Figure 7).

The results indicate that the mixes were not influenced in terms of resilient modulus by the confining pressures applied during the tests. This could be observed for any curing period, what means that is the samples did not likely behave as a granular material, due to the cohesion of the asphalt binder, and the cement hydration. That is the main reason why several researchers have proposed the characterization of cold recycled mixes with asphalt emulsion by means of dynamic testing (Giuliani and Rastelli 2004; Stimilli et al. 2013; Č́ížková et al. 2015). Mr values increased between the first 7 and 28 days of curing in approximately $24 \%$, but after 28 days there was no major increase on the specimens' rigidity, especially after 60 days, in which the recycled mixes presented values of Mr that did not change significantly. It is important to state that six specimens were tested for each curing period and that the variation among the results was very small (coefficient of variation lower than 10\%). After the Mr tests, the specimens were submitted to the ITS (3 samples) and the UCS tests ( 3 samples). Figure 8 presents the results. 
The results indicate that the ITS values increased until 60 days of curing. The average values obtained after this period was almost $100 \%$ higher than the one obtained at the first 7 days of curing. Between 60 and 90 days, the average tensile resistance decreased but the values remained very similar, so it is more likely that the minor differences observed are due to the materials and test variability itself. In terms of the variability found among the specimens subjected to the same curing period, the CV values were considered low, once they were all less than or equal to $10 \%$.

In terms of UCS, the results had the same trend observed for the Mr and ITS tests. Values of resistance tended to increase with the increasing of curing time, resulting in ultimate values that were $100 \%$ higher than the ones observed in the first 7 days of curing. After 60 days, the compressive strength remained constant until the last curing age (90 days). CV values were also low for this test (less than 15\%). For both ITS and UCS tests results, the Student's t test was done to compare the values obtained between 28 and 60 days of curing, and between 60 and 90 days of curing. The test resulted in p-values that were higher than the level of significance (Table 2), which means that the average values can be considered as statistically equals for the given set of curing periods.

\subsection{Accelerated curing}

In order to accelerate the curing of the cold recycled mixes, for laboratory design purposes, different curing temperatures and times were investigated, with the objective of predicting the ultimate mechanical properties of these mixes in a faster and more practical process. A total of 27 specimens with same emulsion, water, and cement contents (3.0, 5.5, and 1.0\%, respectively) were

produced, and the temperatures $\left(40,60\right.$, and $\left.100^{\circ} \mathrm{C}\right)$, and periods $(1,3$, and 7 days $)$ were combined, 
having 9 sets of different curing processes. It is important to state that the materials contents were based on the experimental test site constructed in a very heavy traffic highway in Brazil, which was part of a project described and detailed on Bessa et al. (2016).

At this point of the study, only ITS tests were performed, once this is the parameter generally used in the design of cold recycled mixes in Brazil. The specimens were submitted to the tests at the standard temperature $\left(25^{\circ} \mathrm{C}\right)$, so this means that after each curing process was finished, the specimens were stabilized to this temperature during a period of at least 5 hours. Figure 9 presents the ITS results for each temperature and each curing time.

The results indicate that using higher temperatures for curing processes can provide benefits for the design of cold recycled mixes with emulsion, once their final mechanical characteristics can be achieved in less time in comparison to the $25^{\circ} \mathrm{C}$ curing temperature (that is believed to be a temperature more similar to the temperature of this mixture in the field, once it is usually applied as a binder, or base layer). At the temperature of $40^{\circ} \mathrm{C}$ and after only 1 day, the specimens presented ITS values that were very similar to the ones obtained for mixes at $25^{\circ} \mathrm{C}$ after 7 days of curing. Increasing the curing period until 7 days also increased the resistance. The temperature of $60^{\circ} \mathrm{C}$ presented higher results, when compared to $40^{\circ} \mathrm{C}$. The resistance achieved at this temperature in each curing age was the highest among all the curing temperatures studied. The results at $60^{\circ} \mathrm{C}$ were even higher than the strength found at the temperature of $100^{\circ} \mathrm{C}$, which might be explained by a possible deterioration of the mixes' internal structure caused by the elevated temperature. Also, the temperature of $100^{\circ} \mathrm{C}$ might have quickly eliminated part of the water that would be used for cement hydration, and this would also have prevented the mixes to gain the resistance. Figure 10 presents the increase of ITS values with the increasing of curing time, and 
compares the results from the conventional curing process (at $25^{\circ} \mathrm{C}$ ) with the results from the accelerated curing (at higher temperatures).

The results show that after 7 days of curing, all the tested temperatures $\left(40,60\right.$ and $\left.100^{\circ} \mathrm{C}\right)$ produced mixes with similar ITS values, which might indicate that this is the limit of strength gain for this type of mix. The temperature of $60^{\circ} \mathrm{C}$ produced the most resistant mixes in terms of ITS. After 1 day, the referred temperature was able to reach an average ITS value of $0.5 \mathrm{MPa}$, which was close to the value obtained for the curing process at $40^{\circ} \mathrm{C}$ after 7 days.

The ITS results for the curing method performed at $25^{\circ} \mathrm{C}$ clearly reached an average maximum value after 28 days of curing. This value is even lower than the ones obtained for the other temperatures in lower curing ages. The resistance of mixes at $25^{\circ} \mathrm{C}$, after 60 or 90 days of curing, could be reached at the temperature of $60^{\circ} \mathrm{C}$ after only 1 day. This indicates that the accelerated curing method might be a good tool for designing of this type of recycled mix. After all the studies done considering different curing temperatures and periods, a cold recycled mixes design method can be proposed.

\section{PROPOSITION OF COLD RECYCLED MIXES DESIGN METHOD}

A protocol is proposed in this research paper for the cold recycled mixes design. The aggregate composition should consist of $100 \%$ of RAP materials, with a nominal maximum aggregate size (NMAS) of $19 \mathrm{~mm}$ or lower; the asphalt emulsion can be modified or non-modified; the hydraulic additive should be cement or hydrated lime; and the water must be distilled. For compaction and curing processes, the Proctor compactor equipment and an oven capable of functioning at $60^{\circ} \mathrm{C}$, with precision of $1^{\circ} \mathrm{C}$, must be used. 
The blending process consists in primarily mixing the RAP with the cement (or other hydraulic binder) at the amount desired. After that, the water is added, and then, the asphalt emulsion should be the last material to be added to the mix. The compaction process done with the use of the modified Proctor compaction should provide 100m-diamater and 200mm-height specimens.

In order to obtain the optimum asphalt emulsion, cement, and water contents, a few steps should be considered. First, three asphalt emulsion contents should be selected, with a variation of $1 \%$ among them. These contents should consist of values that are close to what is normally used in the field applications, according to RAP gradation and past experiences. For each emulsion content, five specimens with different water contents should be produced; the emulsion content that provides the highest values of maximum dry density should be selected for the following steps. After that, three cement contents should be chosen. UCS tests should be performed in the different specimens that were cured at $60^{\circ} \mathrm{C}$ for 1 day, and the cement content that provides the best results (and higher that $0.20 \mathrm{MPa}$ ) should be selected. The test speed should be $1 \mathrm{~mm}$ per minute, and one must take care on stabilizing the temperature of the specimens at $25^{\circ} \mathrm{C}$ for at least five hours before the test begins.

In relation to ITS tests, the minimum value must be $0.40 \mathrm{MPa}$ after 1 day of curing at the temperature of $60^{\circ} \mathrm{C}$. The test must be done at the temperature of $25^{\circ} \mathrm{C}$, and at the speed of $50 \mathrm{~mm}$ per minute. This time of curing, coupled with the temperature proposed, were found to provide the maximum strength that the cold recycled mixes can achieve.

The quantification of the binder dispersion into the sample was not considered in this study. The 
authors agree it is an important issue to be addressed in future work, since curing at $60^{\circ} \mathrm{C}$ (above the binder's softening point) may cause redistribution of the asphalt, and consequently may change the sample's permeability.

\section{SUMMARY AND CONCLUSIONS}

This paper aimed to propose a laboratory design method for cold recycled mixes with addition of asphalt emulsion and Portland cement. Marshall and Proctor compactions were used and the mixes constituents' percentages were varied in order to obtain optimum contents of water, asphalt emulsion and cement. Mechanical tests (Mr, ITS and UCS) were performed after different curing temperatures and periods. In general, Marshall-compacted specimens were not significantly influenced by the variation of their materials contents, while Proctor-compacted specimens presented variation on their mechanical behavior as asphalt emulsion and cement contents were varied.

The main contribution of this study is to provide a methodology for cold recycled mix design that includes the compaction method to be used and the process for defining the optimum contents of water, asphalt emulsion and cement. The Proctor hammer compaction is recommended once it seems to be more appropriate for this type of mix. The design procedure should include at least three asphalt emulsion contents. Five samples for each emulsion content should be prepared, with variation on their water content in order to obtain the optimum moisture content. The water present in the asphalt emulsion should be considered. UCS tests are then performed in order to design the $\operatorname{mix}$. 
In relation to the curing procedure, it is recommended that the specimens are submitted to a curing temperature of $60^{\circ} \mathrm{C}$ during only one day. The present study provided results from different curing temperatures and ages and samples cured in this combination of temperature and curing period resulted in mixes with mechanical behavior related to ITS that were similar to what was found after 28 days at the temperature of $25^{\circ} \mathrm{C}$. It is important to state that the conclusions provided here are acceptable for the gradation distribution of the cold recycled mixes produced in this research. Other aggregate size distributions might lead to different results and relations. Another issue that should be further investigated is the influence of the proposed higher temperature $\left(60^{\circ} \mathrm{C}\right)$ in the asphalt dispersion into the sample and in some potential change in its permeability.

\section{ACKNOWLEDGEMENTS}

The authors would like to acknowledge the financial support of CAPES, CNPq and ANTT; and Arteris for providing the materials used in the research.

\section{REFERENCES}

Asphalt Recycling and Reclaiming Association (ARRA). 2001. Basic Asphalt Recycling Manual., US, Department of Transportation.

Asphalt Academy. 2002. The Design and Use of Foamed Bitumen Treated Materials. CSIR Transportek, Pretoria, South Africa.

Asphalt Academy. 2009. Technical Guideline: Bitumen Stabilised Materials, A Guideline for the Design and Construction of Bitumen Emulsion and Foamed Bitumen Stabilised Materials. 2nd edition, Pretoria, South Africa,. 
ASTM D6929. 2010. Standard practice for preparation of bituminous specimens using Marshall apparatus. American Society for Testing and Materials, ASTM, West Conshohocken, PA.

Attoh-Okine, B. 2012. RAP methodology: previous experimental results and creep behavior with geocell reinforcement. Available from http://sites.udel.edu/dct/files/2013/10/Rpt.-233-Recycled-Asphalt-Pavement-Okine-qsagax.pdf.

Austroads Project. 2011. Review of foamed bitumen stabilisation mix design methods. Austroads Technical. Report AP-T178/11, Austroads Project No. TT1358. Available from http://www.auststab.com.au/austroads/AP-T178-11.pdf.

Baker, D., Wourms, O., Berthelot, C., Gerbrandt, R. 2000. Cold in-place recycling using asphalt emulsion for strengthening for Saskatchewan low volume roads. Canadian Technical Asphalt Association Proceedings, 45th. Annual Conference 47: 145-166. Available from https://www.researchgate.net/publication/237561859_cold_in-place_recycling_using_asphalt_e mulsion_for_strengthening_for_saskatchewan_low_volume_roads.

Batista, F.A., and Antunes, M.L. 2006. Desempenho de misturas betuminosas recicladas a frio. Comunicações Pavimentos Rodovários Verdes. [In Portuguese]

Behiry, A.E.A.E. 2012. Laboratory evaluation of resistance to moisture damage in asphalt mixtures. Ain Shams Engineering Journal 4(3): 351-363. doi: 10.1016/j.asej.2012.10.009. 
Bessa, I.S., Aranha, A.L., Vasconcelos, K.L., Bernucci, L.L.B., Silva, A.H.M., and Chaves, J.M. 2014. Caracterização mecânica de misturas asfálticas recicladas a frio. 21o. Encontro de Asfalto. [In Portuguese]

Bessa, I.S., Aranha, A.L., Vasconcelos, K.L., Silva, A.H.M., and Bernucci, L.L.B. 2016. Laboratory and field evaluation of recycled unbound layers with cement for use in asphalt pavement rehabilitation. Materials and Structures 49(7): 2669-2680. doi: $10.1617 / \mathrm{s} 11527-015-0675-6$.

Charmot, S., Braham, A., and Zhang, K. 2013. Effect of emulsion content and cement loading on cold recycling mixture fracture energy measured using the semi circular bending fracture test. Transportation Research Board 92nd. Annual Meeting. Available from https://trid.trb.org/view.aspx?id=1241738.

Chiu, C., Hsu, T., and Yang, W. 2008. Life cycle assessment on using recycled materials for rehabilitating asphalt pavements. Resources, Conservation and Recycling 52(3): 545-556. doi: doi:10.1016/j.resconrec.2007.07.001.

Čížková, Z., Suda, J., Valentin, J., and Krpálek, O. 2015. Stiffness and complex modulus of cold recycled mixes. Bituminous mixtures and pavements VI: proceedings of the 6th International Conference on Bituminous Mixtures and Pavements.

Dafalla, M.A. 2013. Effects of clay and moisture content on direct shear tests for clay-sand mixtures. Advances in Materials Science and Engineering 2013. doi: 
http://dx.doi.org/10.1155/2013/562726.

David, D. 2006. Misturas asfálticas recicladas a frio: estudo em laboratório utilizando emulsão e agente de reciclagem emulsionado. M.Sc. thesis, Escola de Engenharia, Universidade Federal do Rio Grande do Sul, Porto Alegre, RS. [In Portuguese]

Fu, P., Jones, D., Harvey, J.T., and Bukhari, S.A. 2009. Laboratory test methods for foamed asphalt mix resilient modulus. Road Materials and Pavement Design 10(1): 188-212. doi: 10.1080/14680629.2009.9690187.

Gao, L., Ni, F., Charmot, S., and Luo, H. 2014. Influence on compaction of cold recycled mixes with emulsions using the Superpave gyratory compaction. J. Mater. Civ. Eng. 26(11). doi: 10.1061/(ASCE)MT.1943-5533.0000987.

Giani, M.I., Dotelli, G., Brandini, N., and Zampori, L. 2015. Comparative life cycle assessment of asphalt pavements using reclaimed asphalt, warm mix technology and cold-in-place recycling. Resources, Conservation and Recycling 104(A): 224-238. doi:10.1016/j.resconrec.2015.08.006.

Giuliani, F., and Rastelli, S. 2004. An analytical approach to evaluate the performance of cold recycled asphalt mixtures. International RILEM Conference on the Use of Recycled Materials in Buildings and Structures.

Godenzoni, C., Graziani, A., and Perraton, D. 2016. Complex modulus characterisation of cold-recycled mixtures with foamed bitumen and different contents of reclaimed asphalt [online]. 
Road Materials and Pavement Design. doi: 10.1080/14680629.2016.1142467.

Kavussi, A., and Modarres, A. 2010. A model for resilient modulus determination of recycled mixes with bitumen emulsion and cement from ITS testing results. Construction and Building Materials 24(11): 2252-2259. doi:10.1016/j.conbuildmat.2010.04.031.

Kim, Y., and Lee, H. 2006. Development of mix design procedure for cold in-place recycling with foamed asphalt. J. Mater. Civ. Eng. 18(1): 116-124. doi:

10.1061/(ASCE)0899-1561(2006)18:1(116).

Kim, Y., Im, S., and Lee, H.D. 2011. Impacts of curing time and moisture content on engineering properties of cold in-place recycling mixtures using foamed or emulsified asphalt. J. Mater. Civ. Eng. 23(5): 542- 553. doi: 10.1061/(ASCE)MT.1943-5533.000020.

Kuna, K., Airey, G., and Thom, N. 2016. Mix design considerations of foamed bitumen mixtures with reclaimed asphalt pavement material [online]. International Journal of Pavement Engineering. doi: 10.1080/10298436.2015.1126271.

Lee, H.D., and Kim, Y. Development of a mix design process for cold in-place rehabilitation using foamed asphalt. 2003. Final Report for TR-474 Phase I. Iowa Department Transportation; Available from https://core.ac.uk/download/files/358/11345708.pdf. 
Lee, K.W., Brayton, T.E., Mueller, M, and Singh, A. 2016. Rational mix-design procedure for cold in-place recycling asphalt mixtures and performance prediction. J. Mater. Civ. Eng. 28 (6). doi: 10.1061/(ASCE)MT.1943-5533.0001492.

Martinéz, A., Miró, R., and Pérez-Jiménez, F. 2007. Spanish experience with the application of gyratory compactor and indirect tensile test in design and control of cold recycled asphalt pavement. Transportation Research Record: Journal of the Transportation Research Board (2001): 163-168. doi: http://dx.doi.org/10.3141/2001-18.

Minnesota Department of Transportation (MnDOT). 2000. Cold in-place recycling literature review and preliminary mixture design procedure. Final Report. Available from http://www.cts.umn.edu/Publications/ResearchReports/reportdetail.html?id=605.

Modarres, A., Nejad, F.M., Kavussi, A., Hassini, A., and Shabanzadeh, E. 2011. A parametric study on the laboratory fatigue characteristics of recycled mixes. Construction and Building Materials 25 (4): 2085-2093. doi:10.1016/j.conbuildmat.2010.11.030.

Motta, R., Bernucci, L., Vasconcellos, P., Faria, V., and Leal, J.F.. 2014. Laboratory and field evaluation of warm mix asphalt in Brazil. Transportation Research Board Annual Meeting. Available from https://trid.trb.org/view.aspx?id=1289669.

Niazi, Y., and Jalili, M. 2009. Effect of Portland cement and lime additives on properties of cold in-place recycled mixtures with asphalt emulsion. Construction and Building Materials 23(3): 1338-1343. doi:10.1016/j.conbuildmat.2008.07.020. 
Perraton, D., Tebaldi, G., Dave, E., Bilodeau, F., Giacomello, G., Grilli, A., Graziani, A., Bocci, M., Grenfell, J., Muraya, P., Pasetto, M., Kuna, K., Apeagyei, A., Lo Presti, D., Airey, G., Jenkins, K., Hajj, E., Hugener, M., and Marsac, P. 2016. Tests campaign analysis to evaluate the capability of fragmentation test to characterize recycled asphalt pavement (RAP) material. 8th. RILEM International Symposium on Testing and Characterization of Sustainable and Innovative Bituminous Materials, RILEM Bookseries (11): 965-976. doi: 10.1007/978-94-017-7342-3_77.

Recasens, J.R.M., Pérez-Jiménez, F.E., and Aguilar, S.C. 2000. Mixed recycling with emulsion and cement of asphalt pavements: design procedure and improvements achieved. Materials and Structures 33(5): 324-330. doi: 10.1007/BF02479703.

Sebaaly, P.E., Bazi, G., Hitti, E., Weitzel, D., and Bemanian, S. 2004. Performance of cold In-place recycling in Nevada. Transportation Research Record: Journal of the Transportation Research Board (1896): 162-169. doi: http://dx.doi.org/10.3141/1896-16.

Silva, A.H.M., Vasconcelos, K.L., Aranha, A.L., Bernucci, L.L.B., and Chaves, J.M. 2013. Laboratory and field evaluation of cold in-place RAP recycling. 92nd. Annual Meeting Compendium of Papers. Transportation Research Board Annual Meeting. Available from https://trid.trb.org/view.aspx?id=1089621.

Stimilli, A., Ferrotti, G., Graziani, A., and Canestrati, F. 2013. Performance evaluation of a cold-recycled mixture containing high percentage of reclaimed asphalt. Road Materials and Pavement Design 14(S1): 149-161. doi:10.1080/14680629.2013.774752. 
Tebaldi, G., Dave, E., Marsac, P., Muraya, P., Hugener, M., Pasetto, M., Graziani, A., Grilli, A., Bocci, M., Marradi, A., Wendling, L., Gaudefroy, V., Jenkins, K., Loizos, A., and Canestrari, F. 2014. Synthesis of standards and procedures for specimen preparation and in-field evaluation of cold-recycled asphalt mixtures. Road Materials and Pavement Design 15 (2): 272-299. doi:10.1080/14680629.2013.866707.

Thanaya, I.N.A., Zoorob, S.E., and Forth, J.P. 2009. A laboratory study on cold-mix, cold-lay emulsion mixtures. Proceedings of the Institution of Civil Engineers: Transport 162(TR1): 47-55. doi:10.1680/tran.2009.162.1.47.

Thenoux, G., González, A., and Dowling, R. 2007. Energy consumption comparison for different asphalt pavements rehabilitation techniques used in Chile. Resources, Conservation and Recycling 49(4): 325-339. doi:10.1016/j.resconrec.2006.02.005.

Wirtgen GmbH. Wirtgen cold recycling manual, 2nd edition. Windhagen, Germany, 2012.

Xu, J., Huang, S., Qin, Y., and Li, F. 2011. The impact of cement contents on the properties of asphalt emulsion stabilized cold recycling mixtures. Int. J. Pavement Res. Technol. 4(1): 48-55. Available from https://rid.trb.org/view.aspx?id=1089621.

Yang, J., Ddamba, S., UL-Islam, R., Safiuddin, Md., and Tighe, S.L. 2014. Investigation on use of recycled asphalt shingles in Ontario hot mix asphalt: a Canadian case study. Canadian Journal of Civil Engineering 41(2): 136-143. doi:10.1139/cjce-2013-0022. 
Table 1 Summary of previous studies

\begin{tabular}{|c|c|c|}
\hline Country & Source & Curing process \\
\hline Spain & Recasens et al. (2002) & $\begin{array}{l}\text { Several curing periods in order to evaluate the different } \\
\text { effects }\end{array}$ \\
\hline South Africa & $\begin{array}{l}\text { Asphalt Academy } \\
\qquad(2002)\end{array}$ & $\begin{array}{c}25^{\circ} \mathrm{C} \text { for } 24 \text { hours (non-sealed specimen) }+40^{\circ} \mathrm{C} \text { for } 48 \\
\text { hours (sealed specimen) }\end{array}$ \\
\hline USA & Sebaaly et al. (2004) & $\begin{array}{c}\text { Initial curing at } 25^{\circ} \mathrm{C} \text { for } 15 \text { hours }+ \text { curing at room } \\
\text { temperature for } 3 \text { hours after removing the molds } \\
\text { Final curing at } 60^{\circ} \mathrm{C} \text { for } 3 \text { days after removing the } \\
\text { molds }+ \text { curing at room temperature for } 3 \text { days } \\
\text { Long-term curing at } 60^{\circ} \mathrm{C} \text { for } 30 \text { days }\end{array}$ \\
\hline Germany & Wirtgen GmbH (2006) & $\begin{array}{c}40^{\circ} \mathrm{C} \text { for } 24 \text { hours (non-sealed specimen) }+40^{\circ} \mathrm{C} \text { for } 48 \\
\text { hours (sealed specimen) }\end{array}$ \\
\hline Brazil & David (2006) & $\begin{array}{l}\text { Curing at } 60^{\circ} \text { for } 24 \text { hours }+ \text { curing at room } \\
\text { temperature before removing the mold }\end{array}$ \\
\hline Spain & Martinéz et al. (2007) & Curing at $60^{\circ} \mathrm{C}$ for 3 days \\
\hline Iran & Niazi e Jalili (2009) & $\begin{array}{l}\text { Curing at } 60^{\circ} \mathrm{C} \text { for } 24 \text { hours }+ \text { curing at room } \\
\text { temperature for } 24 \text { hours }+ \text { curing at room temperature } \\
\text { for } 5 \text { days (after removing the molds) }\end{array}$ \\
\hline UK & Thanaya et al. (2009) & $\begin{array}{l}\text { Curing at } 40^{\circ} \mathrm{C} \text { for } 18 \text { to } 21 \text { days or } \\
\text { curing at } 25^{\circ} \mathrm{C} \text { for } 24 \text { hours }+ \text { curing at room } \\
\text { temperature for } 1 \text { to } 24 \text { weeks }\end{array}$ \\
\hline USA & Fu et al. (2009) & Curing at $40^{\circ} \mathrm{C}$ for 72 hours \\
\hline Australia & $\begin{array}{l}\text { Austroads project } \\
\qquad(2011)\end{array}$ & Curing at $60^{\circ} \mathrm{C}$ for 3 days \\
\hline Egypt & Behiry (2012) & No curing \\
\hline USA & Attoh-Okine (2012) & Curing at room temperature for 24 hours \\
\hline USA & Lee et al. (2016) & $\begin{array}{c}\text { Curing at } 25^{\circ} \mathrm{C} \text { for } 24 \text { hours }+ \text { curing at } 60^{\circ} \mathrm{C} \text { for } 6 \\
\text { hours }\end{array}$ \\
\hline
\end{tabular}


Table 2 P-values of the Student's t tests

\begin{tabular}{ccc}
\hline Characterization test & Curing periods & P-value \\
\hline $\begin{array}{c}\text { Indirect tensile } \\
\text { strength (ITS) }\end{array}$ & 28 and 60 days & 0.10 \\
\cline { 2 - 3 } $\begin{array}{c}\text { Unconfined } \\
\text { compression strength } \\
\text { (UCS) }\end{array}$ & 28 and 90 days 60 days & 0.12 \\
\cline { 2 - 3 } & 60 and 90 days & 0.15 \\
\hline
\end{tabular}


Fig. 1 Aggregate size distribution

Fig. 2 Relationship between the PCS (\%) and the fragmentation testing temperature $(5 / 10 \mathrm{~mm})$

Fig. 3 Experimental design matrix

Fig. 4 Compaction curves for: (a) emulsion and (b) cement contents variation

Fig. 5 UCS values for mixes with emulsion content variation

Fig. 6 UCS values for mixes with cement content variation

Fig. $7 \mathrm{Mr}$ values vs. confining pressure: (a) 7 and 28, and (b) 60 and 90 days of curing period

Fig. 8 ITS and UCS vs. curing period

Fig. 9 Average ITS values as a function of curing temperature and time

Fig. 10 Conventional curing vs. accelerated curing 


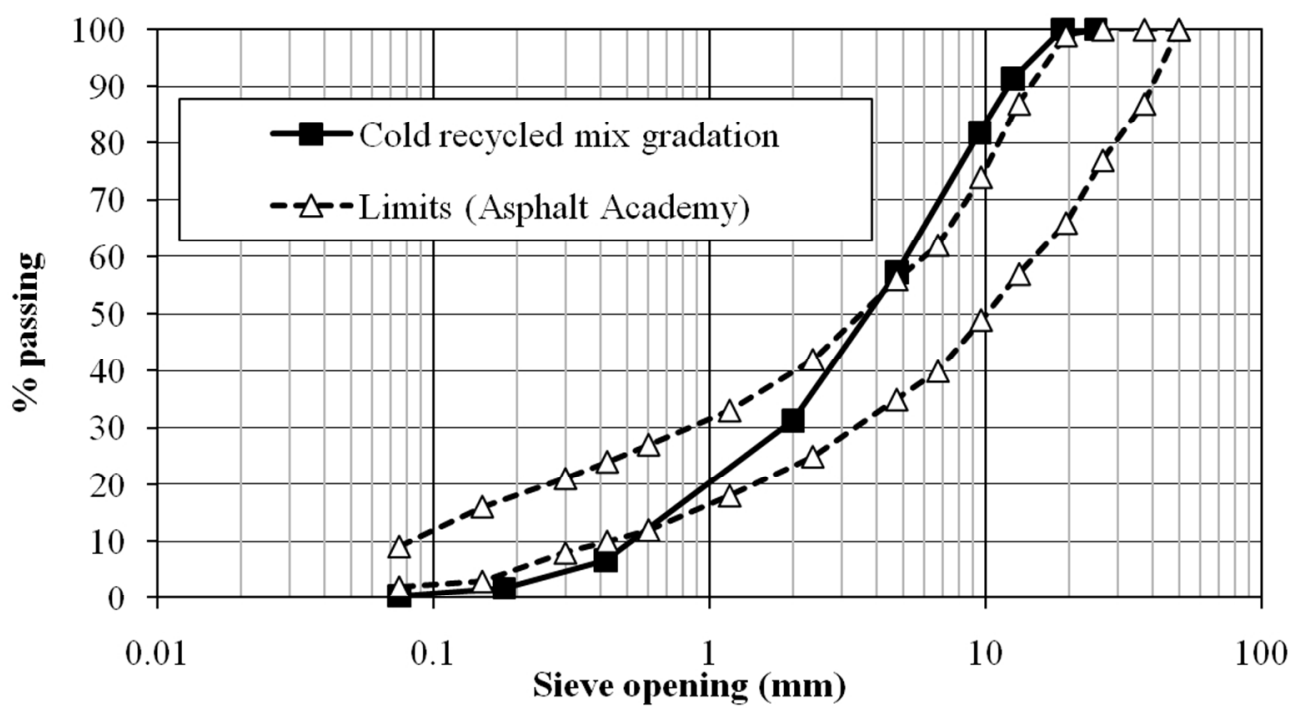

Aggregate size distribution

Figure 1

297×162mm (96 x 96 DPI) 


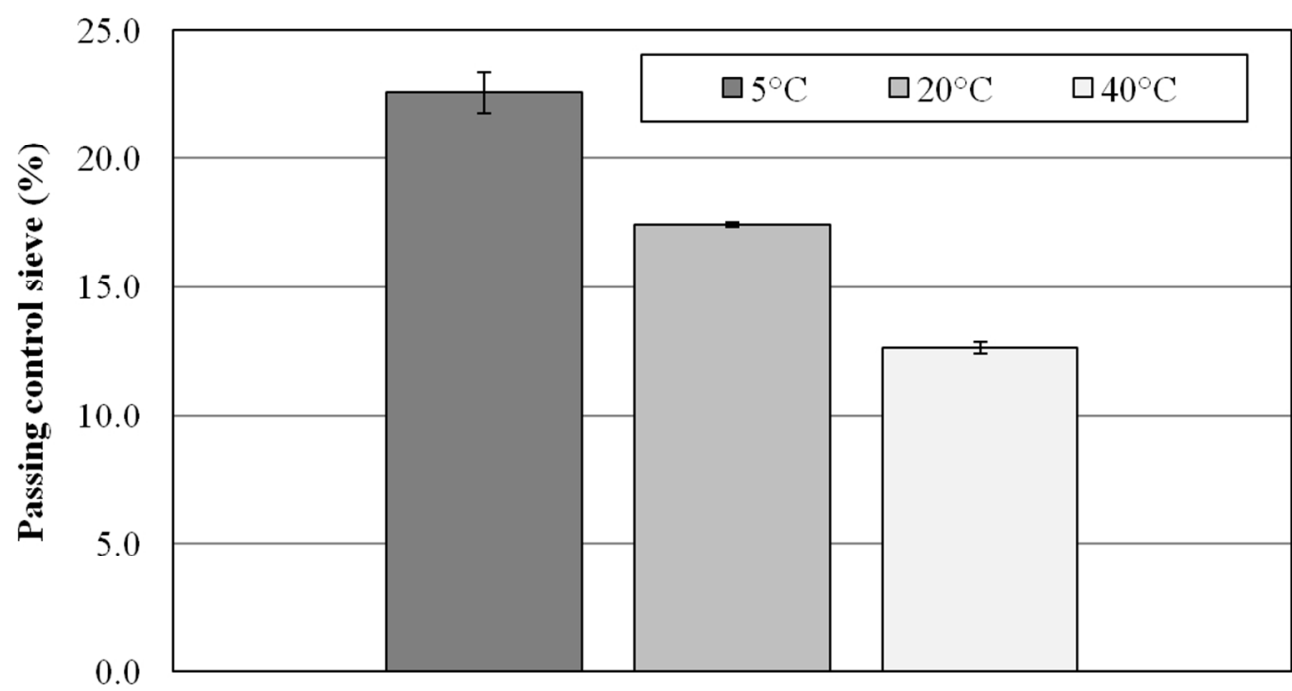

Relationship between the PCS (\%) and the fragmentation testing temperature $(5 / 10 \mathrm{~mm})$ Figure 2 $295 \times 155 \mathrm{~mm}(96 \times 96 \mathrm{DPI})$ 


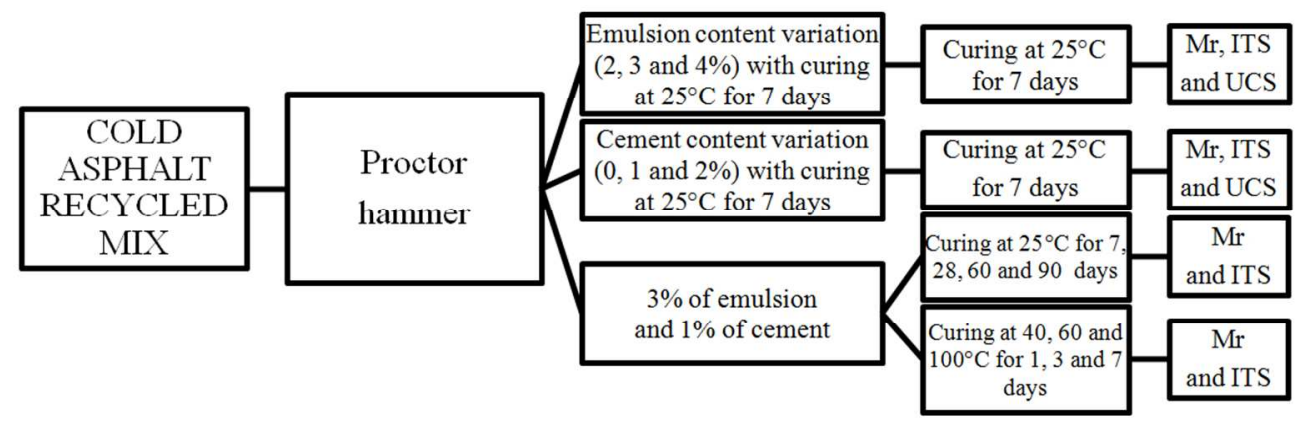

Experimental design matrix

Figure 3

$307 \times 106 \mathrm{~mm}(96 \times 96$ DPI $)$ 


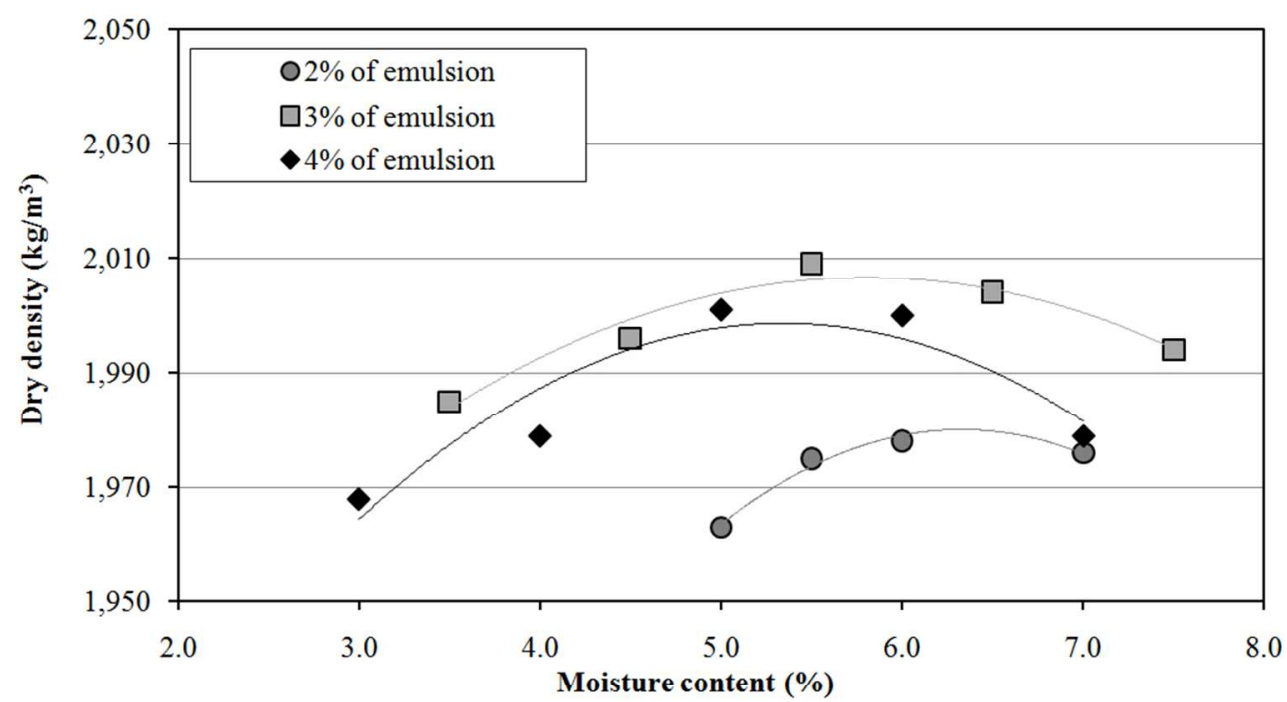

(a)

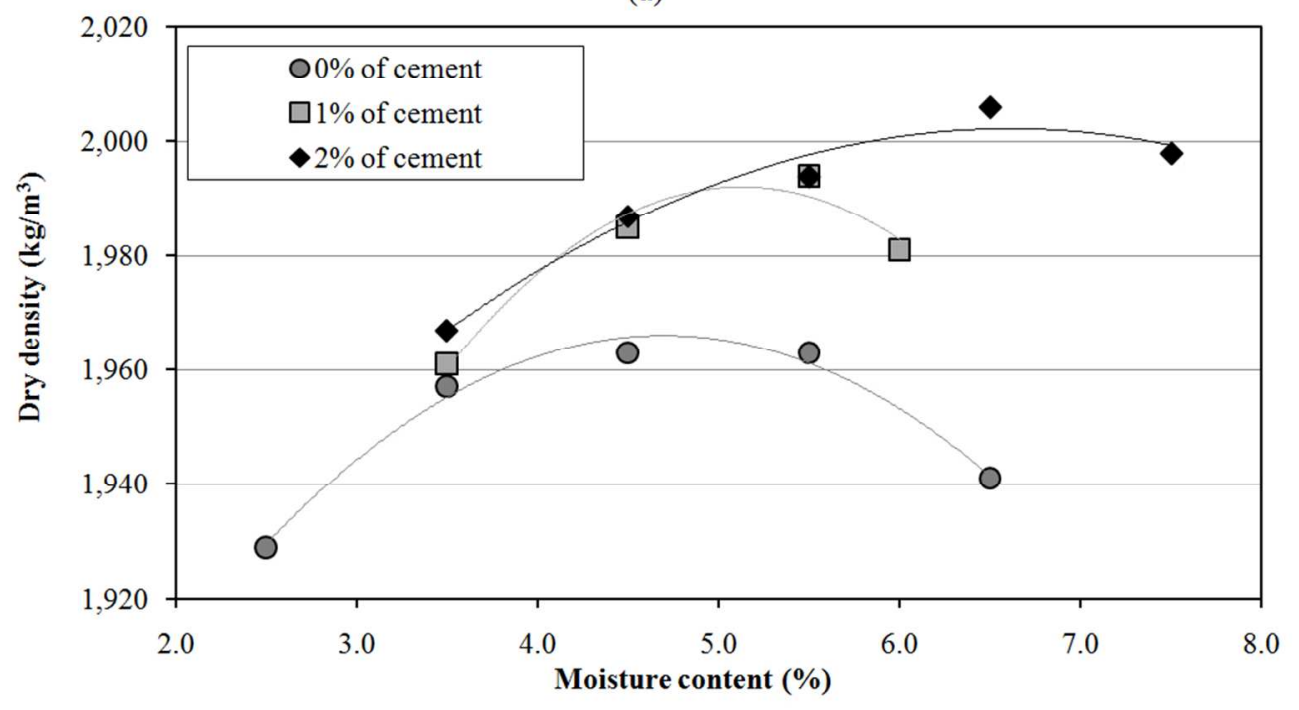

(b)

Compaction curves for: (a) emulsion and (b) cement contents variation

Figure 4

$274 \times 313 \mathrm{~mm}(96 \times 96 \mathrm{DPI})$ 


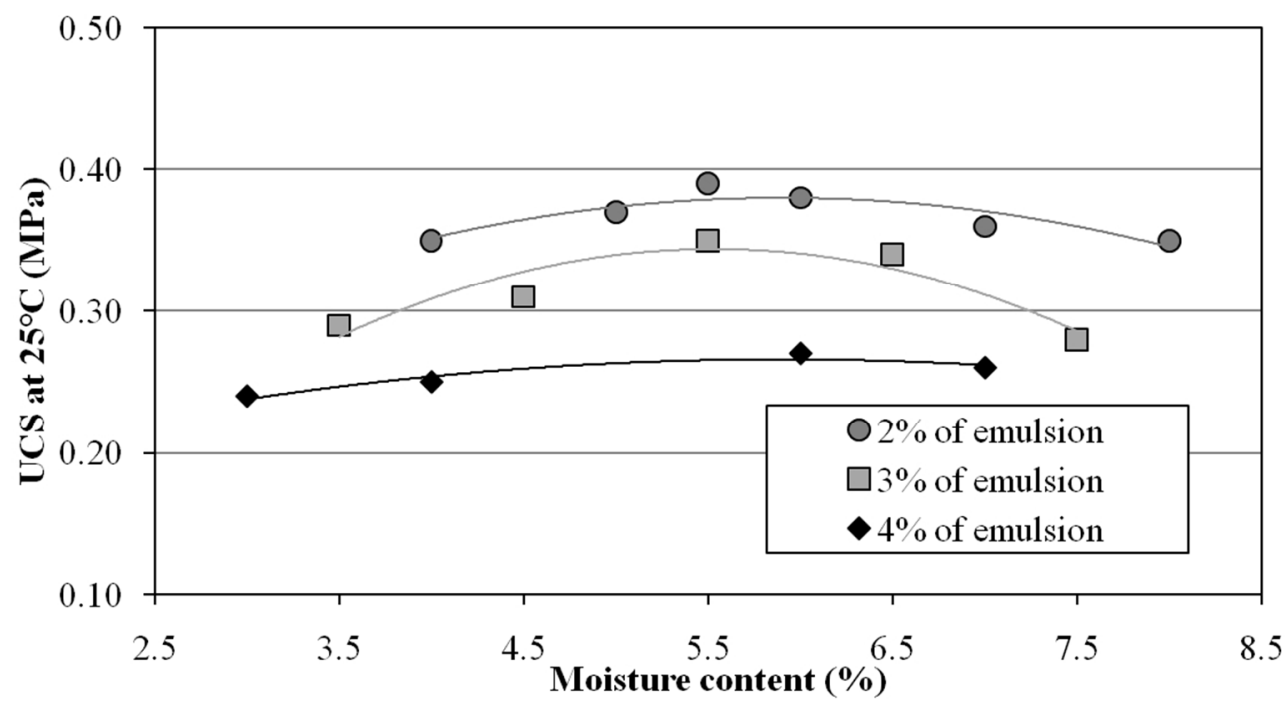

UCS values for mixes with emulsion content variation

Figure 5

$300 \times 161 \mathrm{~mm}(96 \times 96 \mathrm{DPI})$ 


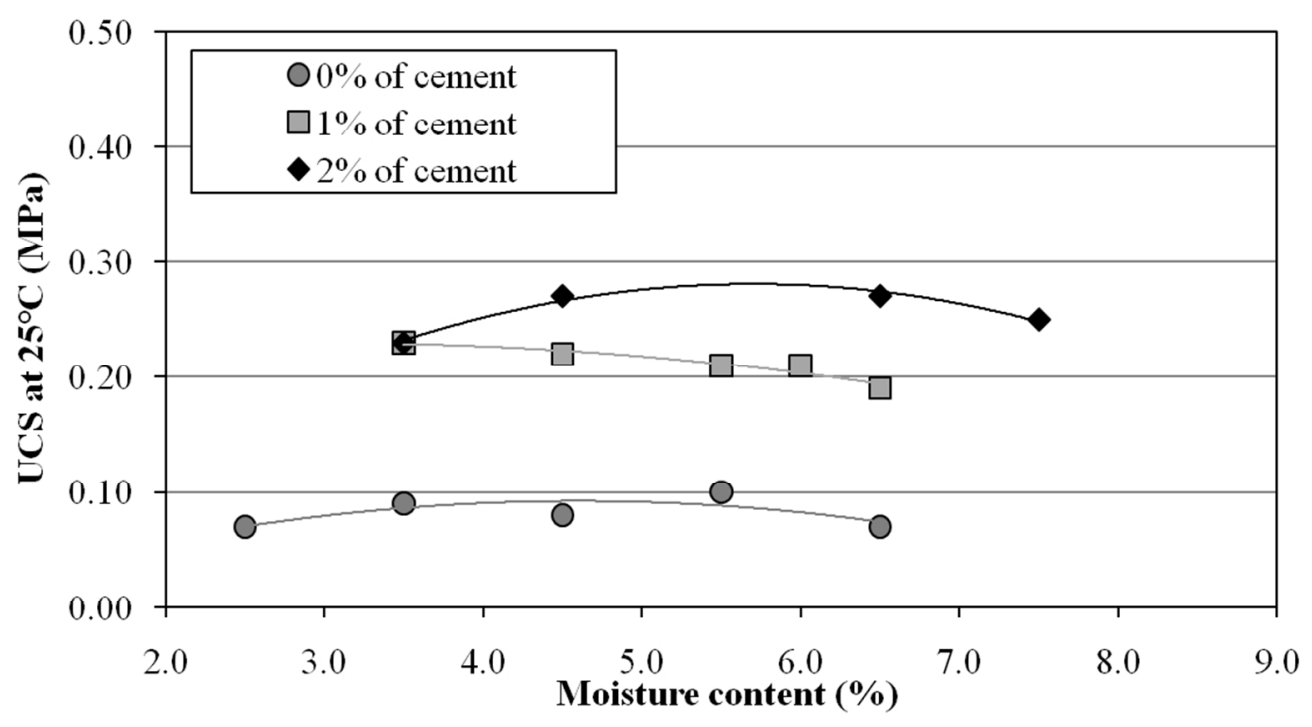

UCS values for mixes with cement content variation

Figure 6

$296 \times 161 \mathrm{~mm}(96 \times 96$ DPI $)$ 


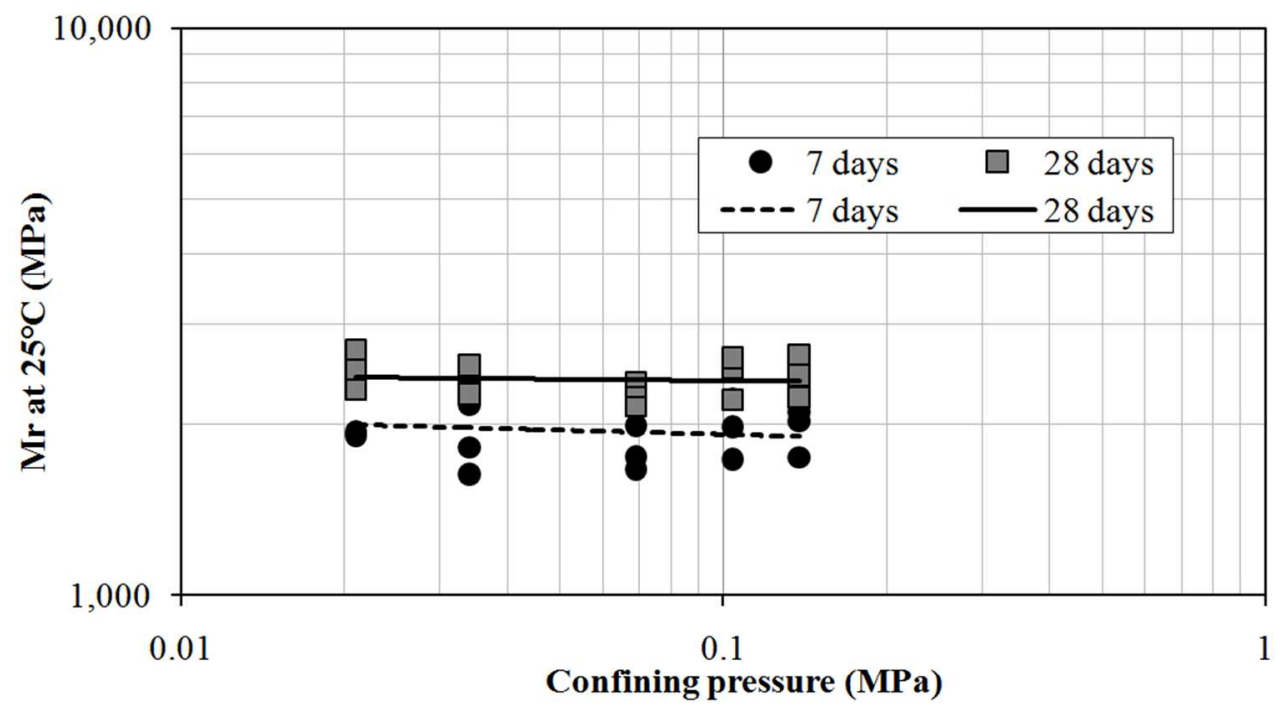

(a)

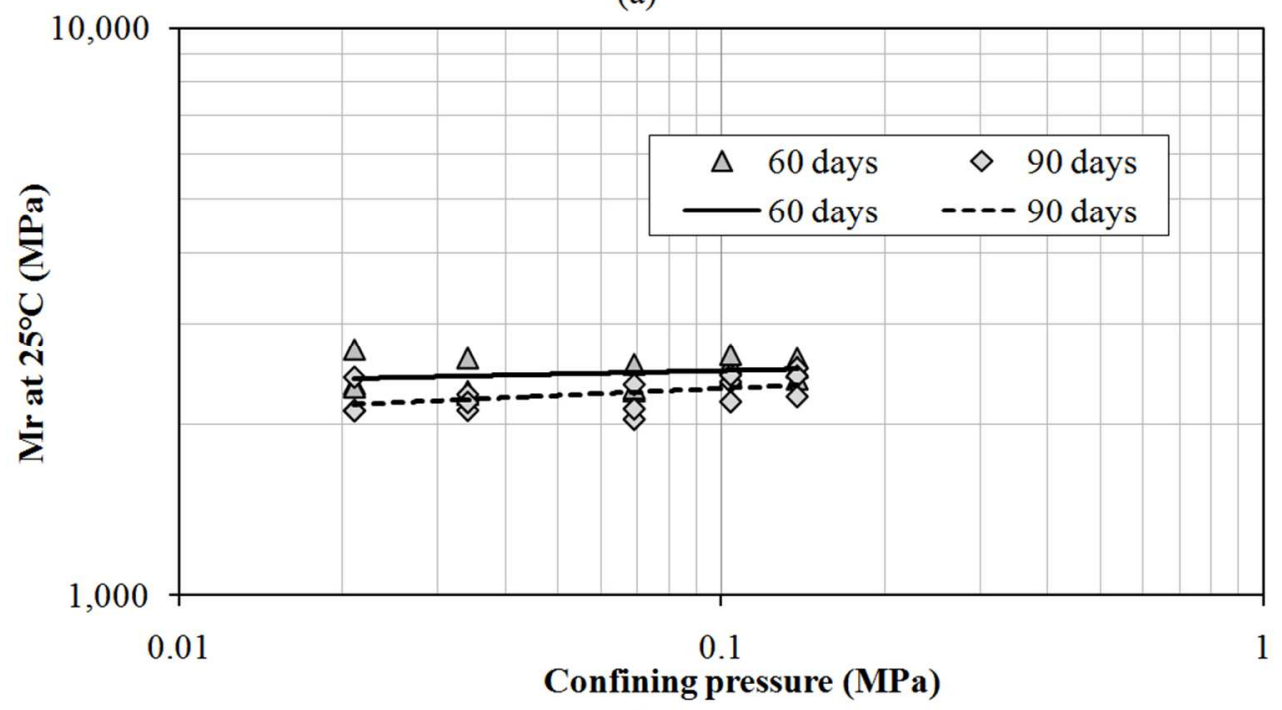

(b)

Mr values vs. confining pressure: (a) 7 and 28, and (b) 60 and 90 days of curing period Figure 7 $278 \times 316 \mathrm{~mm}(96 \times 96$ DPI $)$ 


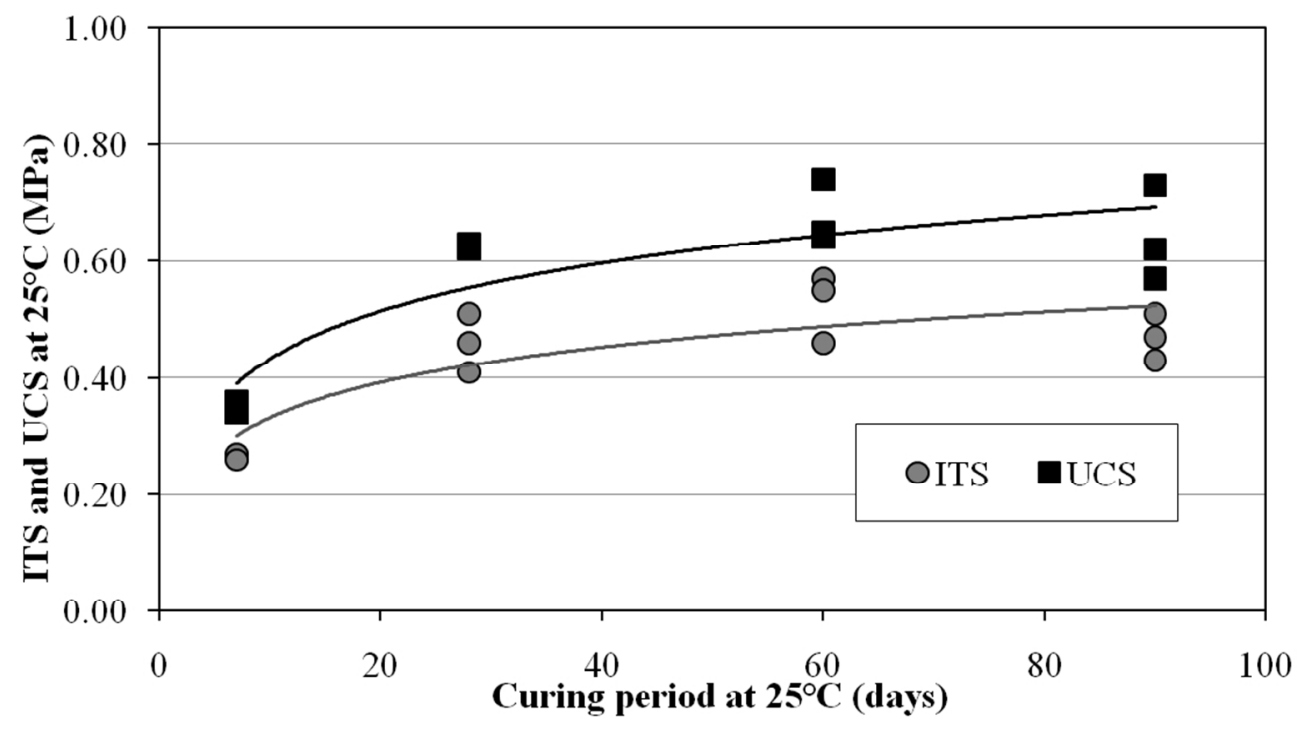

ITS and UCS vs. curing period Figure 8

$296 \times 162 \mathrm{~mm}(96 \times 96$ DPI) 


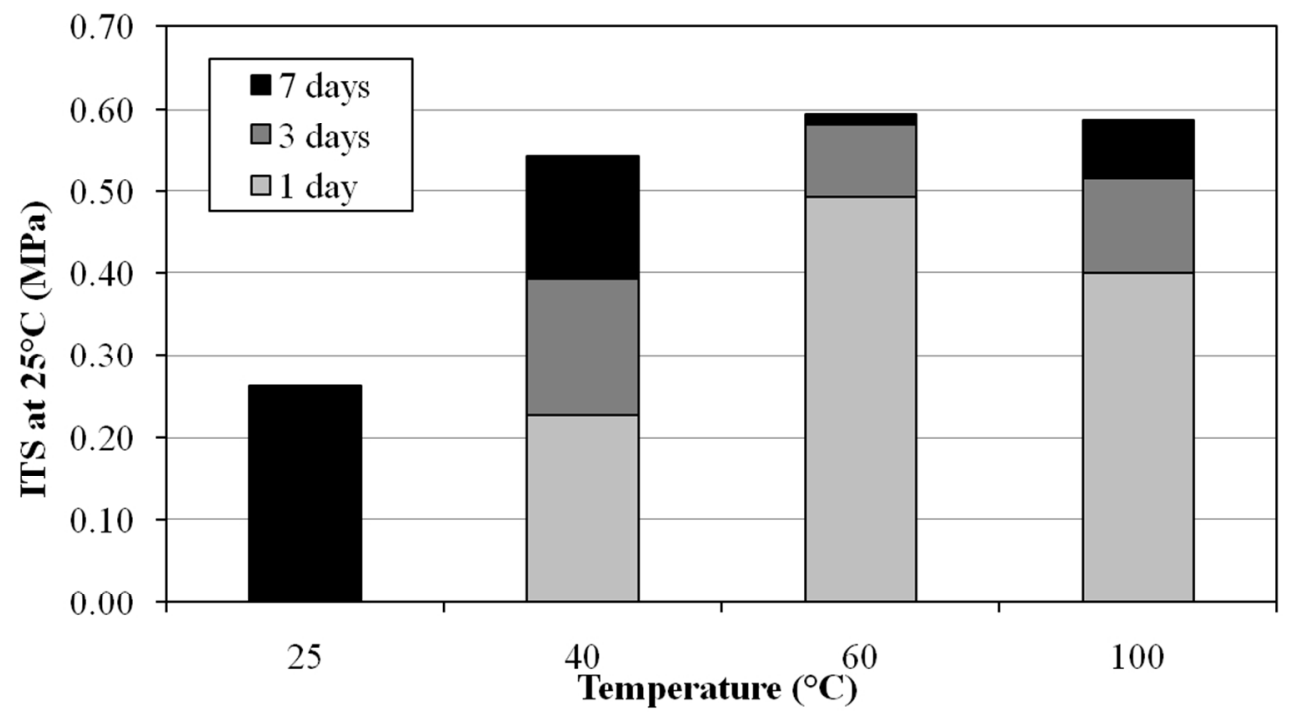

Average ITS values as a function of curing temperature and time Figure 9

$295 \times 160 \mathrm{~mm}(96 \times 96$ DPI $)$ 


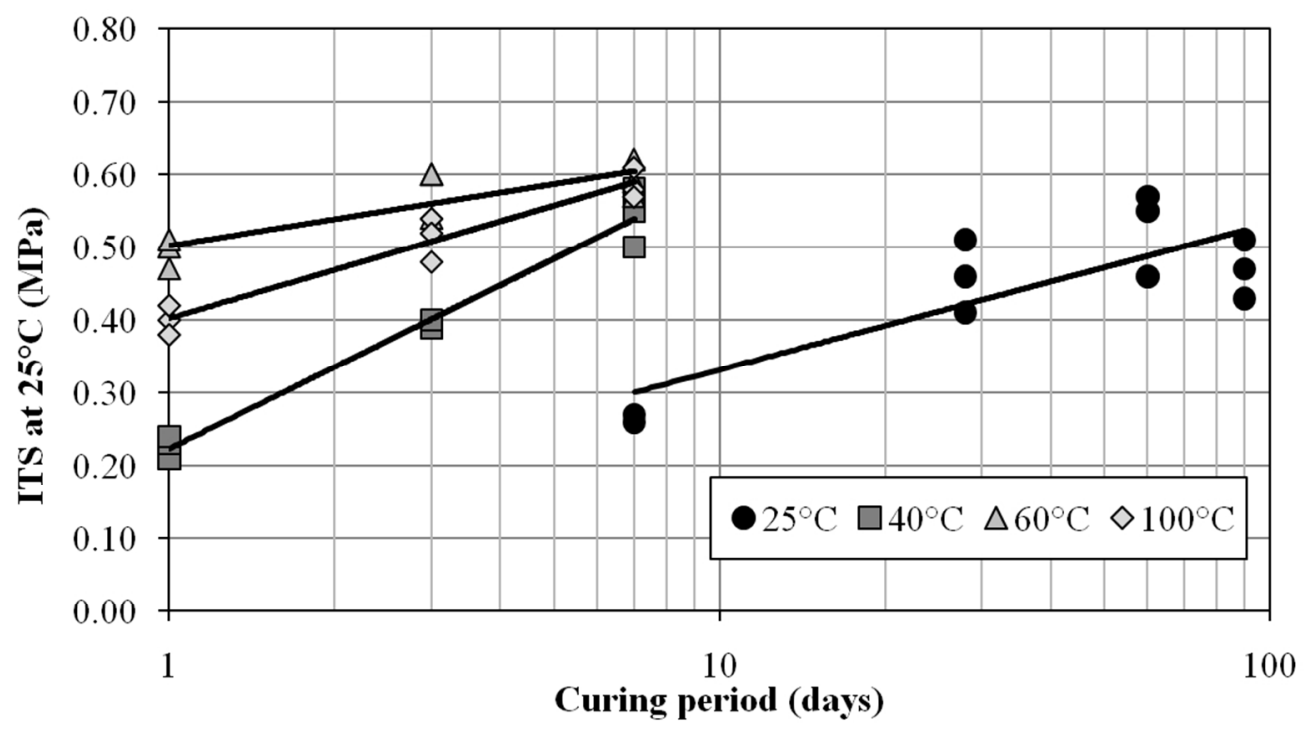

Conventional curing vs. accelerated curing

Figure 10

$297 \times 163 \mathrm{~mm}(96 \times 96$ DPI) 